\title{
FYHE
}

The International J ournal of the First Year in Higher Education ISSN: $1838-2959$

Volume 5, Issue 2, pp. 103-109

August 2014

\section{An evolving approach to developing academics' understanding of transition for first year students. A Practice Report}

Kathy Egea, Neela Griffiths and Jo McKenzie

University of Technology, Sydney, Australia

\begin{abstract}
The purpose of this paper is to describe the strategies used in the First Year Experience (FYE) Project at the University of Technology, Sydney (UTS) to engage and support academics to address student transition and diversity. The UTS FYE framework has provided a mechanism for third generation transition pedagogy which has been realised through a range of strategies including the establishment of a UTS FYE Coordinator overseeing the design and implementation of FYE Forums, the FYE small grant scheme, and supporting the First Year Transition Experience (FYTE) coordinators in faculties. These strategies have resulted in an evolving learning community in which staff have a sense of belonging and identity and their learning is situated and negotiated. The impact of this project on academics is demonstrated through the increasing participation in forums, increasing sophistication of grant applications and the leadership of the FYTE coordinators.
\end{abstract}

Please cite this practice report as:

Egea, K., Griffiths, N., \& McKenzie, J. (2014). An evolving approach to developing academics' understanding of transition for first year students. A Practice Report. The International Journal of the First Year in Higher Education, 5(2), 103-109. doi: 10.5204/intjfyhe.v5i2.235

This practice report has been accepted for publication in Int J FYHE. Please see the Editorial Policies under the 'About' section of the Journal website for further information.

(C) Copyright of practice reports is retained by authors. As an open access journal, articles are free to use, with proper attribution, in educational and other non-commercial settings. ISSN: 1838-2959 


\section{Introduction}

The purpose of this paper is to describe the strategies used in the First Year Experience (FYE) Project at the University of Technology, Sydney (UTS) to engage and support academics to address student transition and diversity within the context of the Widening Participation Strategy (WPS). This university-wide initiative, funded through the WPS, supports the participation, retention and success of all students, particularly those from low socioeconomic status (LSES) backgrounds and indigenous students.

The over-arching organisation of the FYE project at UTS is the UTS FYE framework, a systematic third generation approach (Kift, Nelson \& Clarke, 2010), which emphasises embedding transition pedagogies in the curriculum within an overall top-down and bottom-up institutional framework. The top-down component is enacted through a UTS FYE Coordinator and Faculty First Year Transition Experience (FYTE) Coordinators whilst the bottom-up structure is driven by the buy-in of academic and professional staff through a small grants scheme and facilitated learning community (Egea \& McKenzie, 2012; Egea, McKenzie \& Griffiths, 2013). The UTS FYE Framework draws on Kift et al.'s definition of curriculum as encompassing "all of the academic, social, and support aspects of the student experience" (p.8). This framework places the students at the centre (belonging and sense of identity) within the dimensions of the broader curriculum, academic practice and university infrastructure. It has evolved as a series of diverse but aligned approaches, which have grown since their inception in 2011 (Egea \& McKenzie, 2012).

The institutional framework also depends on academics' individual understandings of how transition pedagogies promote student success in the classroom "one class and one subject at a time" (Tinto, 2012, p.4). However, it is not simply a matter of providing academics teaching first year with resources, it is critical to support their understandings of how to design learning environments that apply these transition pedagogies. This paper suggests that UTS staff perceptions of transition and transition pedagogies have evolved as part of growing conversations on transition at the university, as has the UTS FYE Coordinator's approach to supporting that evolution. This may be of interest to other institutions, particularly those that have faced challenges with academic buy-in for transition pedagogies.

\section{The UTS FYE project: Structure and initiatives}

The initiatives designed in this evolving project enact the FYE framework through the roles of the UTS FYE Coordinator, the Faculty Transition Coordinators and the FYE small grant scheme. It is important to understand all parts of the strategy and how they relate to each other in order to understand how academics' engagement with transition pedagogies has evolved.

\section{FYE Coordinator at UTS}

The role of the UTS FYE Coordinator (established in July 2011) is to encourage and deepen the conversation around supporting transition in the curriculum and learning practices through the design and implementation of a range of FYE project activities. Fundamental to this role is engaging academics and increasing their buy-in, through facilitating the learning community supporting academic engagement in the small grant scheme, organising first year forums and heading 
the First Year Transition Experience (FYTE) faculty coordinators' team.

To support the learning community, the FYE coordinator has created a list of academics involved in FYE grants, staff who attend one or more FYE forums, the FYE advisory group, faculty FYTE Coordinators, senior management in teaching and learning, and professional staff from university infrastructure, library and student support. The learning community list has grown to 320 members (70\% academics, 30\% professional staff) from the original 15 academics.

The coordinator also actively builds synergies between the academic and professional staff and other interested stakeholders. This occurs through the learning community, but also through conversations in student-focused committees with colleagues from the Equity and Diversity Unit (EDU) and the Student Services Unit (SSU), and with the WPS in schools and other student entry pathways.

It has also proved critical to raise the awareness and highlight the relevance of the program with senior management. Within faculties, this is achieved by drawing on first year student data: cohort diversity, success in subjects, programs and overall faculty in comparison with the universitywide statistics. At the university-wide level, this is achieved through presentations to university committees on the successes (for example, increased student achievement and retention resulting from specific first year grant projects) and challenges; and through publishing activities and achievements in UTS publications.

\section{Faculty FYTE Coordinators roles}

FYTE Coordinators (a 0.2 load) were established in each faculty in 2013 to lead and coordinate First Year Transition practices. They are accountable to Associate Deans (Teaching and Learning) and work on a range of strategies to build the conversation around FYE with subject coordinators, heads of school, casual academics and program leaders within their faculty. Through regular meetings with their fellow coordinators and the central FYE project owner and coordinator, they have developed a FYTE learning community which shares practice, and compares goals and achievements. Facultybased approaches to achieve staff buy-in include identifying pedagogical issues (individual meetings with academics), incorporating curriculum changes, and building mentoring programs. Their influence underpins in part a significant increase in interest in the FYE grants for the 2014 round, and growth of the FYE forum.

\section{FYE grants}

The small grants scheme (Egea et al., 2013) provides staff with both the incentive and the practical support to design curriculumbased activities linked to one or two of the First Year Curriculum Principles (FYCP) (Kift, 2009). Academics (full-time and casual) who are teaching or coordinating first year subjects can apply for FYE grants. In applications combining curricular and co-curricular activities, professional staff may form partnerships with academic staff.

\section{The UTS FYE Project: Academic buy-in}

Academic buy-in has been supported by bottom-up initiatives designed to engage the academic staff who work with the first year curriculum. 


\section{FYE grants uptake and evolving understandings}

Since the commencement of the grant scheme in September 2011, academics from all faculties have been involved. Over the four rounds of FYE grants (2011-2014), of the 93 applications submitted, 75 have received grant funding ( $\$ 1000-\$ 4000)$. Applications are funded (in part) on the link between the FYCPs and the innovation in classroom practice. Table 1 highlights the overall increase in the total number of grant applications and the rate of growth since 2011 and the growing academic interest in the FYE approach.
1991) for academics in the grant writing process. This involves negotiating meaning, providing scaffolded support through feedback, improving guidelines and exemplars. This process has been increasingly supported by the academic language and literacy experts, and the FYTE Coordinators.

\section{The FYE learning community at UTS}

The university-wide FYE learning community is, in effect, a community of practice (Lave \& Wenger, 1991) enabling UTS staff to participate in the social process of learning. This participation provides a

Table 1: FYE grants 2011 to 2014

\begin{tabular}{|l|c|c|c|c|}
\hline FYE grants & $\mathbf{2 0 1 1 - 2 0 1 2}$ & $\mathbf{2 0 1 2}$ & $\mathbf{2 0 1 3}$ & $\mathbf{2 0 1 4}$ \\
\hline Total applications (funded applications) & $18(14)$ & $15(15)$ & $25(20)$ & $35(27)$ \\
\hline
\end{tabular}

The growing conversation around transition has also had an impact on the quality of the grant applications, particularly in addressing the FYCPs and how they are demonstrated in the curriculum approach. In the earlier iteration of the grants, it was evident that some applicants did not have a good grasp of the FYCPs and relied on a general interpretation of the principle. For example, in 2011, the FYCP for Diversity was understood as a concept of cohort deficiency in which so-called at-risk students needed to be monitored. While in the 2014 applications, the principle of Diversity was embraced positively student diversity was seen as a given, with students needing strategies for peer learning and making links with university support. As befits a community of practice, the FYE UTS Coordinator has identified the need for situated learning (Lave \& Wenger, "look-out post" so that "what one engages with influences one's learning about the structure and culture of the community's practice" (Handley, den Outer \& Price, 2013, p. 891). The community is a place for academics from diverse disciplines to network, share, and build synergies across disciplines and with professional staff. Central to the UTS FYE learning community are the FYE forums. Five forums are held per year at different times to enable maximum attendance. Staff are busy so the two-hour forums include food to encourage attendance and provide a space for extended discussion and networking. Careful planning goes into the forum organisation and selection of topics and activities that align to transition themes supported by FYE grants. Initially, the topics addressed aspects of student transition, but now, after successful completion of 48 FYE grants by the end of 
2013 (see Table 1), the forums are themed to encourage staff to share outcomes from similar grants. Presentations are chosen to both engage staff in growing the conversations around student transition and to build "a sense of the 'structure' of the practice” (Handley et al., 2013, p. 891). Forum attendance depends on the topic, with typically $50-70 \%$ academic staff, and $30-50 \%$ professional staff, with a few external participants. faculties. With funding, two faculties have developed successful CoPs which have enabled faculty staff to participate in learning communities. These not only focus on faculty-specific issues but also highlight their first year grant achievements. The other faculties are developing this model.

Table 2: Mean and standard deviation of survey items rating the value of the FYE forum
Likert scale instrument (1-5) with 5 representing most effective measure
\begin{tabular}{|l|l|l|l|l|}
\hline Value of FYE forums & \multicolumn{2}{l|}{$\mathbf{2 0 1 2}(\mathrm{n}=50)$} & $\mathbf{2 0 1 3}(\mathrm{n}=39)$ \\
\cline { 2 - 6 } & mean & SD & mean & SD \\
\hline $\begin{array}{l}\text { Sharing ideas on teaching/student support with colleagues } \\
\text { from other areas }\end{array}$ & 4.3 & 0.9 & 4.6 & 0.5 \\
\hline $\begin{array}{l}\text { Discussing issues relevant to teaching/supporting students } \\
\text { who are new to UTS }\end{array}$ & 4.2 & 0.9 & 4.3 & 0.9 \\
\hline $\begin{array}{l}\text { Feeling part of a supportive community that is interested in FY } \\
\text { students and transition }\end{array}$ & 4.3 & 0.9 & 4.5 & 0.7 \\
\hline $\begin{array}{l}\text { Learning more about services or resources that can support } \\
\text { students }\end{array}$ & 4.0 & 0.9 & 4.3 & 0.8 \\
\hline Overall, I am satisfied with my experience of the FYE forums & 4.1 & 0.9 & 4.5 & 0.6 \\
\hline
\end{tabular}

Evaluation surveys on the forums were completed in 2012 and 2013. Table 2 demonstrates that the FYE forums are a means to build community and shared practice. Comments from the 2013 survey reflect growing interest in these learning communities and networking opportunities. Comments include: Learning about innovations developed by other academics; The networking and seeing FYE experience in action; and, Contacts, experiences and resources.

\section{Faculty Communities of Practice (CoPs)}

In 2012, a more focused approach to transition pedagogy was trialled within

\section{Conclusion}

This paper illustrates one approach to building academic engagement in transition and transition pedagogies, through a supportive process of evolving and growing conversations on transition. The overarching structure of the FYE project: UTS Framework, Coordinators, small grant scheme and learning communities, are essential components in enabling this to occur. The success of this FYE project in fostering engagement is demonstrated through the increasing participation in forums, grant applications and the leadership of the FYE and FYTE coordinators. Providing academics with opportunities to be connected via a shared 
community of practice and to take part in activities targeted at situated learning on transition, engages and rewards success, and develops a sense of belonging and identity within the first year conversation, a similar finding to McMurray and Scott (2013) as positive factors for organisational change. The impact of the FYE project on student transition is further evidenced in the recent 2013 University Experience Survey in which our commencing students were significantly more satisfied than later year students in the areas of teaching quality, student support and learning resources.

\section{Overview of session outcomes}

The session participants considered UTS's evolving approach to supporting and developing academics' understanding of first year transition as a successful means of achieving academic buy-in and engagement in Transition Pedagogy across the university - See Figure 1 (Kift, 2014a; Kift, 2014b).

1. What challenges has your institution faced in engaging academics in transition practice?

Challenges included: a general lack of institutional coordination or focus around FYE despite the national focus on widening participation and transition strategies; limited buy-in by academics who use a traditional approach, particularly as the reward system (promotion) favours discipline-based research and publication; academic expectations of student entry skills; lack of recognition/support for teaching innovation for full time academics; increasing casualisation in first year classes, with sessional academics having limited opportunities to influence curriculum design.

\section{How were the challenges overcome?}

For many staff (academic and professional), intrinsic motivation and FYE support underpins their involvement in the FYE space. Other academics highlight reward practices-such as promotional systems that recognise teaching-focused research,

108 The International J ournal of the First Year in Higher Education, 5(2) August, 2014 
or workload models that reward time for innovation in teaching-as drivers for engagement in good practice to support students in first year transition.

FYE programs are funded internally and through Higher Education Participation and Partnership Program (HEPPP) offering a range of academic and professional roles. One institutional example of HEPPP-funded programs described how FYE coordinators (academic/student advisors) worked with academics on curriculum design but more often worked in the extended social curriculum for instance first-in-family "family nights". An institutionally-funded FYE project linked an accreditation framework to FY curriculum design and assessment. Another embedded change through the use of standardised assessment rubrics available through their learning management systems.

\section{References}

Egea, K., \& McKenzie, J. (2012). Developing a systematic institutional FYE approach from top down to grassroots up. Retrieved from: fyhe.com.au/past papers/papers12/Papers/2C. pdf

Egea, K., McKenzie, J., \& Griffiths, N. (2013). Achieving academic engagement: Supporting academics to embed first year transition pedagogies in the curriculum. Retrieved from: fyhe.com.au/past papers/papers13/2E.pdf

Handley, K., den Outer, B., \& Price, M. (2013). Learning to mark: Exemplars, dialogue and participation in assessment communities. Higher Education Research and Development, 32(6), 888-900. doi: 10.1080/07294360.2013.806438

Kift, S. (2009). Articulating a transition pedagogy to scaffold and to enhance the first year student learning experience in Australian Higher Education: Final Report for ALTC Senior Fellowship Program.

Kift, S. [KiftSally] (2014a, July 6). How UTS co-ords are getting Faculty buy-in. What's in it for... \#fyhe14 pic.twitter.com/vUQ3yGRH5n [Tweet]. Retrieved from
https://twitter.com/KiftSally/status/48598537 $\underline{9573460992}$

Kift, S. [KiftSally] (2014b, July 6). UTS FYE Transition Pedagogy buy-in through grants \& FYE Forums to share practice. \#fyhe2014 pic.twitter.com/OXc04DF5XM [Tweet]. Retrieved from https://twitter.com/KiftSally/status/48598306 $1700382722 /$ photo/1

Kift, S., Nelson, K., \& Clarke, J. (2010). Transition pedagogy: A third generation approach to FYE A case study of policy and practice for the higher education sector. The International Journal of the First Year in Higher Education, 1(1), 1-20. doi: 10.5204/intjfyhe.v1i1.13

McMurray, A., \& Scott, D. (2013). Determinants for organisational climate for academia. Higher Education Research and Development, 32(6), 960-974. doi: 10.1080/07294360.2013.806446

Lave, J., \& Wenger, E. (1991). Situated learning. Cambridge, UK: Cambridge University Press.

Tinto, V. (2012). Enhancing student success. Taking the classroom seriously. The International Journal of the First Year in Higher Education, 3(1), 1-8. doi:10.5204/intjfyhe.v3i1.119

The International J ournal of the First Year in Higher Education, 5(2) August, $2014 \mid 109$ 